\title{
A Study of Corporate Governance as a Tool of Value Creation in India
}

\author{
Dr. Tanuja Kaushik \\ Professor \& HoD, School of Management, \\ G.D.Goenka University, Sohna Road, Delhi (NCR) \\ Arpana Singh \\ Research Scholar, School of Management, \\ G.D.Goenka University, Sohna Road, Delhi (NCR)
}

\begin{abstract}
In the present era the interest of modern corporations are in corporate governance practices, basically in relation to accountability, increasing level of the high-profile collapses of a number of large corporations during 2001-2002, most of which involved accounting fraud; and then again after the recent financial crisis in 2008. Corporate scandals always attracted the public and political interest in the regulation of corporate governance. Corporate governance is required to build a corporate culture of consciousness, transparency and openness. It includes the combination of laws, rules, regulations, procedures and voluntary practices to enable the companies to maximize the shareholders' long-term value. This paper analysed that corporate governance practices of the sampled companies in association with the mandatory recommendations of Kumar Manglam Birla committee for improving it in India. Authors have sourced the data from S.K Gupta study. He has taken the opinion of the company secretaries and Chartered Accountants are associated on the question of adequacy of corporate governance measures available in India in today's scenario. The evidence collected from 150 respondents and 30 companies situated in and around New Delhi (India). This suggests that only few companies covered in the survey are complying with the mandatory recommendations of Birla Committee.
\end{abstract}

Keywords: Corporate Governance, Ownership, Managers, Shareholders, Financial Crisis, Risk Management.

30

\section{Introduction}

Corporate governance consists of set of rules, duties, principles, ethics, values, morals, regulations, \& procedures etc. Corporate governance leads a system whereby directors are confide with duties and responsibilities in dealings to the direction of the company's affairs.

The literal meaning of "governance" is control i.e. controlling a company, an organization etc. or a company \& corporate governance is governing or controlling the corporate bodies i.e. ethics, values, principles and morals. In the present context corporate governance has become synonymous with the practices and processes used to direct and manage the affairs of a corporate body with the objective of balancing the attainment of corporate objectives with the association of corporate behavior to the expectations of society and accountability to shareholders and other stakeholders.

Corporate governance having a base of principles such as conducting the business with integrity and fairness, being transparent in transactions, making necessary disclosures and decisions, complying with the laws, accountability and responsibility towards the stakeholders and commitment to conduct business in an ethical manner.

\section{Corporate Governance: Definition and Importance}

"Happy companies have robust growth in revenues, strong balance sheets and healthy profits that reflect genuine business success, not phony book keeping. 
ABBS Financial Markets

And they share other important traits as well. They abide by high ethical standards, which is a key to their solid success. They don't obstruct the flow of information to shareholders, but rather view the shareholder as the ultimate owner and the ultimate boss. They choose directors on the strength of their abilities, character and capacity for independent judgment. And their internal controls work well, so that the company's executives can take immediate corrective action when something goes wrong."

- Chairman Christopher Cox,

U.S. Securities and Exchange Commission,

Washington D.C., March 21, 2006.

(Remarks before the Committee for Economic Development.)

An important part of Corporate Governance is timely and accurate discloser of information about the financial situation, performance, ownership and Governance of the company. It improves public understanding of the structure, activities and policies of the organization. Consequently, the organization is able to attract investors and enhance the trust and confidence of the stakeholders.

\section{Governance and Management:}

The terms 'governance' and 'management' are used interchangeably though conceptual difference exits between the two. The main difference lies in activity orientation - the governance is "strategy oriented" whereas management is "task oriented". The management concerns itself with 'execution of tasks' in order to achieve pre-determined goals and objectives. The focus under governance is wider than management; it encompasses framing of policy and ensuring disclosure and transparency. The focus under 'management' is internal - to control, direct and monitor the activities of the management personnel and executives and to make them accountable for proper implementation of pre-determined polices. On the other way, the focus under governance is external - it involves accountability of promoters and directors to the outside world, namely, the stakeholders. Though the concepts are distinctive, there is a common thread, which establishes irrefutable inter-relation between the two -

"Better governance leads to better management".

\section{Who are Stakeholders?}

The focus under Corporate Governance is shifted from 'shareholders' to 'stakeholders'. Nobel Prize winner in Economics, Milton Friedman linked Corporate Governance to the conduct of business in accordance with the shareholders' desires, which primarily meant to create wealth for shareholders/ owners but at the same time conforming to the laws, rules, regulations and customs established by the society. The Corporate Governance is no longer restricted to creation of wealth for the shareholders. The concept now encompasses interest of stakeholders. But who really are the stakeholders?

The stakeholders include, besides the shareholders, other participants in the corporation such as the Board of Directors, managers, employees, workers, customers, vendors, lenders, and community goals can't be overlooked under the Corporate Governance.

For good corporate governance it's necessary for a manager to meet its responsibilities towards its owners (shareholders), creditors, employees, customers, government and the society at large.

For achieving effective corporate governance, it's necessary that policies need to be such that the directors of the company should not exploit their power and instead should understand their duties and responsibilities towards the company and should act in the best interests of the company in the broadest sense.

The concept of 'corporate governance' is not an end; it's just a beginning towards growth of company for long term prosperity.

Corporate governance concept emerged in India after the second half of 1996 due to economic liberalization and deregulation of industry and 
ABBS Financial Markets

business. With the changing times, there was also need for greater accountability of companies to their shareholders and customers. The report of Cadbury Committee on the financial aspects of corporate Governance in the U.K. has given rise to the debate of Corporate Governance in India.

Numerous studies emanating from academic and non-academic circles over the years show that good Corporate Governance will yield numerous benefits to the investors, company and nation as a whole. Better CG can provide shareholders with greater security on their investment and ensures that shareholders are sufficiently informed on decisions concerning fundamental issues like amendments of statutes or articles of incorporation, sale of assets, etc.

The benefit to a company is that it can raise capital more easily. The company will have support from its stakeholders in a situation of downturn. Any wrong business judgment by the board will not be seen as a scandal but as a consequence of the risk/reward ratio involved in equity investment. The company's business will be more sustainable and its reputation will be enhanced through good Corporate Governance. Good Corporate Governance will also help to survive in an increasingly competitive environment through mergers, acquisitions, partnerships, and risk reduction through asset diversification. Also, adopting good CG practices leads to a better system of internal control, thus leading to greater accountability and better profit margins. Good CG practices can pave the way for possible future growth, diversification, or a sale, including the ability to attract equity investors -nationally and from abroad - as well as reduce the cost of loans/ credit for corporations. It will have good impact on share price and improves business performance thereby improving nation's economy.

In India Confederation of Indian Industry (CII), took a special initiative on Corporate Governance in 1996. The objective was to develop and promote a code for corporate governance to be adopted and followed by Indian companies, in the Private Sector, the Public Sector, Banks or Financial Institutions, all of which are corporate entities. This initiative by $\mathrm{Cll}$ flowed from public concerns regarding the protection of investor's interest especially the small investor, the promotion of transparency within business and industry. As a result the Government of India brought in a separate legislation by the name of Securities and Exchange Board of India (SEBI) Act 1992 and conferred statutory powers to it. Since then, SEBI had introduced several stock market reforms. These reforms significantly transformed the face of Indian Stock Markets. The Kumar Manglam Birla Committee was constituted by SEBI in May 1999, to promote investors' interest and to raise the standards of corporate governance in India. The committee has made 23 mandatory recommendations that have become a benchmark and standard for corporations in India.

This study further deals with literature review, objectives of the study, null hypothesis, research methodology, analysis and findings, conclusions, suggestions for better corporate governance and lastly with references.

\section{Literature Review}

Jenson and Fama, (1983), stated in their study that in modern corporations, basically which are in United States and the United Kingdom, main objective of corporate governance is to ascertain that the interests of top-level managers are aligned with shareholders' interests. Corporate governance gives insights in areas where owners, managers and board of directors may have conflicts of interests. These areas include the selection of directors; supervision of Chief Executive Officer and director's pay; and the corporation's overall structure and strategic direction. Tricker, (1984), in his study explored that there is a significant difference between management and governance. He argued that whereas management is all about running the business, governance is about running it properly. Governance identifies rights and 
ABBS Financial Markets

responsibilities, legitimizes actions and determines accountability.

Felton, Hudnet and Witt, (1995), in their study stated out that the decisions and actions of a corporation's board of directors can be effective deterrent to unethical behaviors. The most important aspect of corporate governance participate actively in setting boundaries for business ethics and values. Rao and Lee Sing,( 1996),explored that good governance practices leads active participation of shareholders in the direct and indirect management of corporation through the board of directors and an arrangement of productive checks and balances among shareholders, board of directors and management of corporations.

Business Today-AIMS, (1997), in their survey of the best board of directors, among the country's 100 most valuable corporate, on the basis of four parameters of corporate governance, i.e. accountability, transparency, quality and independence found that the best five boards in India are Hindustan Lever Limited, Telco Limited, Bajaj Auto Limited, HDFC Limited and Larsen \&Toubro Limited. Mckinsey,( 2002) a researchbased company in its investor-opinion survey of 200 institutional investors showed that threequarters of investors polled regarded board practices to be as important as financial performance. Institutional investors are willing to pay share premium for companies with good corporate governance practices over equivalent companies without good corporate governance practices, range from 18 percent for companies in the U.K. to 27 percent for companies in Indonesia.

An important empirical study by Chakraborty, Megginson\&Yadav (2007) has explored the evolution of Indian corporate governance and identify how this system has supported by the top world rank of economies. Researcher analysis suggest that the framework of the legal system of the country's demonstrated some of the best investor protection in the world; but major problem is the enforcement and slow functioning of overburdened court under the widespread prevalence of corruption. Some of the changes are indicated welcomes sign of maturing corporate sector. SME sector of India involved in relationshipbased informal control and mechanism of governance.

In recent years in spite of low faith in the formal and legal system of governance Indian economy and its financial markets have achieved prominent growth that it is only second to china.

Author stated that the problem pertinent to Indian governance is not unique but similar issues are found in other Asian countries also. In this study author found that major issues are weak legal protection of property whereas it is one of the important factors of concentrating ownership and family owned businesses. Another dominating factor is poor development of external financial market.

A comprehensive study by Balasubaramanian \& Radhakrishnan (2011) explains the clear view about corporate governance best practices and accountability and performance.

"Corporate governance is the set of processes, customs, policies, laws and institutions affecting the way a corporation is directed, administrated or controlled."

In India success of corporate governance depend upon the sound systems of company's operations. To enhance the bar of standard of corporate governance, Kumar manglam committee recommended to form audit committee. Kumar manglam committee propounded that minimum three members should be in committee, one of the member should possess financial and accounting knowledge and majority should be independent with non -executive directors. The chairman of the committee should be independent director and he should present at annual general meeting to handle the shareholders queries and provide answer to shareholders question. Auditors are appointed to 
ABBS Financial Markets

check the books of accounts honestly, companies are also bound to appoint internal auditor but both the auditor are failed to prove their honesty as we experienced lots of scams in India. So, that it became mandatory to rotate auditors committee after every three years.

If market not work for poor and not able to give prosperity to poor corporate governance is not success. In a major issues or conflict is between dominant shareholders and minority shareholders. Foreign companies having restriction on percentage of investment which creates problem for corporate governance as all business are meant to generate profit all though after liberalization MNC's are attracted towards India for investment.

Shivan (2014) declare that Past research recognizes that companies following sound governance practices having good weightage in the market. Author explains that board of directors play a very prominent role in corporate governance, the present study has identified some selected voluntary board practices and examined them with the help of a sample of top listed companies in India. Moreover, this study also underscores the significance of firm size by exposing that the relationships between some of the selected voluntary board practices do vary according to the firm size status. Although the analysis covered in this study presents preliminary investigation, yet the overall findings drawn herein provide implications for the different sizes of companies with respect to the adoption of various voluntary board practices covered.

From the above review it can be concluded that significant efforts have been made by the eminent scholars all over the world to study various aspects of corporate governance practices and their impact on various stakeholders. But no such type of attempt has been made in India so far to study the current corporate governance regime in Indian straddles and to study how far, both voluntary and mandatory requirements, on corporate governance are being implemented to safeguard the interest of various stakeholders'. This study is a humble attempt to bridge the gap

\section{Objectives of the study}

1. To study the current context of corporate Governance in India

2. To examine the role of non-executive directors in context to corporate governance.

3. To evaluate the role of Institutional investor in maintaining good corporate governance.

4. To examine the state of affairs of discloser and transparency practices and financial reporting and auditing practices in Indian companies.

\section{Research Methodology}

The present study is an experimental research in which the rigorous literature review has been done. Secondary data are used to attain objective of study.

\section{Mandatory Recommendations:}

- Applies to listed companies with paid up capital of Rs. 3 crore and above

- Composition of board of directors - optimum combination of executive \& non-executive directors

- Audit committee - with 3 independent directors with one having financial and accounting knowledge.

- Remuneration committee

- Board procedures - at least 4 meetings of the board in a year with maximum gap of 4 months between 2 meetings. To review operational plans, capital budgets, quarterly results, minutes of committee's meeting. Director shall not be a member of more than 10 committee and shall not act as chairman of more than 5 committees across all companies

- Management discussion and analysis report covering industry structure, opportunities, threats, risks, outlook, internal control system

- Information sharing with shareholders 
ABBS $\quad$ Financial Markets

\section{Compliance of Kumar Manglam Birla Committee Recommendations}

The $\mathrm{KBC}$ gave recommendations which are compulsory for directors, management, employees and professionals associated with all listed private and public sector companies in India in accordance with the time schedule mentioned in report. A scoring system was developed to measure the extent of adoption of the KBC report's mandatory recommendations. Each recommendation has been assigned a score 0 or 1 by the committee. If a recommendation is being followed it has been assigned score 1 and if it is not being followed by the companies, score 0 has been given. This test was done on 30 companies following corporate Governance mandatory recommendations.

Company following mandatory recommendations

\begin{tabular}{|c|c|}
\hline $\begin{array}{c}\text { No. of Mandatory } \\
\text { Recommendation }\end{array}$ & No. of Companies \\
\hline 16 & 2 \\
\hline 17 & - \\
\hline 18 & 5 \\
\hline 19 & 8 \\
\hline 20 & 6 \\
\hline 21 & 2 \\
\hline 22 & 3 \\
\hline 23 & 4 \\
\hline Total & $\mathbf{3 0}$ \\
\hline
\end{tabular}

Source: S. K. Gupta "Governance Practices in Developing Nations: An Empirical Study of India" World Journal of Social Sciences Vol. 5. No. 1.January 2015 Issue. Pp. 51 - 66

Table shows that only 4 companies are fully following all mandatory recommendations. These companies are GTL Limited, Kotak Mahidra Limited, Mahindra and Mahindra Limited and Ansal Housing and Construction Limited. While the average of the 30 companies with corporate governance recommendations is $19.8(594 / 30)$.

\section{Appointment of non-executive Directors}

\begin{tabular}{|c|c|c|}
\hline S.No. & $\begin{array}{c}\text { Method of } \\
\text { Appointment }\end{array}$ & $\begin{array}{c}\text { Percentage of } \\
\text { Agreed } \\
\text { Respondents }\end{array}$ \\
\hline 1 & $\begin{array}{c}\text { A panel of Eminent } \\
\text { persons maintained } \\
\text { by the company. }\end{array}$ & 33 \\
\hline 2 & $\begin{array}{c}\text { Among the names } \\
\text { finalized by the } \\
\text { nomination committee } \\
\text { who are persons of } \\
\text { eminence and proven } \\
\text { track record. }\end{array}$ & \\
\hline 3 & $\begin{array}{c}\text { Among the persons } \\
\text { working as directors / } \\
\text { senior professionals in } \\
\text { other companies. }\end{array}$ & \\
\hline 4 & $\begin{array}{c}\text { Among the names } \\
\text { proposed and approved } \\
\text { by the shareholders. }\end{array}$ & 80 \\
\hline
\end{tabular}

Source: S. K. Gupta "Governance Practices in Developing Nations: An Empirical Study of India" World Journal of Social Sciences Vol. 5. No. 1.January 2015 Issue. Pp. $51-66$

Table depicts that 93 percent respondents have agreed that non-executive directors must be appointed from the list which is proposed and approved by the shareholders.

\section{Role of Institutional Investors}

\begin{tabular}{|l|l|c|}
\hline S.No & Role & $\begin{array}{c}\text { No. of } \\
\text { Respondents }\end{array}$ \\
\hline 1 & $\begin{array}{l}\text { Take Active interest in the } \\
\text { composition of the Board } \\
\text { of Directors. }\end{array}$ & $22(73)$ \\
\hline 2 & $\begin{array}{l}\text { Maintain regular and } \\
\text { systematic contact at } \\
\text { senior level for exchange } \\
\text { of views on management, } \\
\text { strategy, performance and } \\
\text { the quality of management. }\end{array}$ & $20(67)$ \\
\hline 3 & $\begin{array}{l}\text { Ensure that voting intentions } \\
\text { are translated into practice. }\end{array}$ & $21(70)$ \\
\hline 4 & $\begin{array}{l}\text { Evaluate the corporate } \\
\text { Governance performance of } \\
\text { the company. }\end{array}$ & 23 \\
\hline
\end{tabular}


ABBS Financial Markets

Source: S. K. Gupta "Governance Practices in Developing Nations: An Empirical Study of India" World Journal of Social Sciences Vol. 5. No. 1.January 2015 Issue. Pp. 51 - 66

The above table depicts that majority of respondents advocated all the four variables to comply by the institutional investors for better corporate governance practices in Indian corporations.

Factors strengthening the role of Company Secretary

\begin{tabular}{|l|l|c|}
\hline S.No. & Factors & $\begin{array}{c}\text { No. of } \\
\text { respondents }\end{array}$ \\
\hline 1 & $\begin{array}{l}\text { Vital Role played in ensuring } \\
\text { good corporate governance. }\end{array}$ & 13 (43) \\
\hline 2 & $\begin{array}{l}\text { Can play an effective role by } \\
\text { being recognized as an } \\
\text { ex-officio director on the } \\
\text { Board of a Company. }\end{array}$ & $15(50)$ \\
\hline 3 & $\begin{array}{l}\text { Participation in evolving the } \\
\text { best corporate practices. }\end{array}$ & $17(57)$ \\
\hline 4 & $\begin{array}{l}\text { Areas of disclosure must go } \\
\text { beyond the traditional areas } \\
\text { of financial and legal } \\
\text { compliance. }\end{array}$ & 30 (100) \\
\hline
\end{tabular}

Source: S. K. Gupta "Governance Practices in Developing Nations: An Empirical Study of India" World Journal of Social Sciences Vol. 5. No. 1.January 2015 Issue. Pp. 51 - 66

It is clear from the Table that all the respondents agreed that areas of disclosures must go beyond the traditional areas of financial and legal compliances. It should include non-financial information like environmental issues, social responsibility of business and related areas. These may be included in the Director's report to shareholders. Only selective companies are disclosing such details to the shareholders.

\section{Conclusions}

Most of the companies strive to have a high level of corporate governance. These days, it is not enough for a company to merely be profitable; it also needs to demonstrate good corporate citizenship through environmental awareness, ethical behavior and sound corporate governance practices. Since the late 1990s, Indian regulators have significantly put efforts, as well as by Indian industry representatives and companies, to overhaul Indian corporate governance. For listed companies, the vast majority of Clause 49 requirements are mandatory. It remains to be seen whether some of the more recent voluntary corporate governance measures will become mandatory for all companies through a comprehensive revision of the Companies Act.

The Committee's recommendations are not based on any one model but are basically designed for the purpose of Indian environment. Corporate governance extends beyond corporate law. The Committee believes that its recommendations will go a long way in raising the standards of corporate governance in Indian firms and make them attractive destinations for local and global capital. These recommendations will also form the base for further evolution of the structure of corporate governance in corporate with the rapidly changing economic and industrial environment of the country in the new millennium.

However, corporate governance ultimate objective to attain highest standard of procedures and practices followed by the corporate world so as to have transparency in its functioning with an ultimate aim to maximize the value of various stakeholders

\section{References}

Business Today-AIMS 1997, 'Research survey: best boards', Business Today 7-21 March, pp. 76-84. Cadbury, A 1998, 'Corporate governance: The widening debate', The Economic Times, Vol. Il p.9.

Centre for Monitoring Indian Economy 2001, 'Unlisted companies and Corporate Governance', Business World, Vol. IV, p. 49. Chakrabarti Rajesh, Megginson William L. \&YadavPradeep K (2007),'Corporate Governance 
in India ',Journal of Applied Corporate Finance, Volume 20, Issue 1, pp 8-134.

Chartered Institute of Management Accountant of Britain 2000, 'The Global experience: governing corporate', The Chartered accountant, Vol. III, pp 23-29.

Chandler, Alfred D 1962, 'Strategy and structure: chapters in the business history of the Industrial enterprise', Harvard Business School press, Boston.

Erkens, D, Hung, M and Matos, P 2010, 'Corporate governance in the 2007-2008 financial crises: evidence from financial institutions worldwide', ECGI Finance working Paper No. 249/ 2009. http://papers.ssrn.com/sol3/papers.cfm, Abstract id $=1397685$.

Felton, RE, Hudnet, A and Witt, V 1995, 'Building a stronger board', Mckinsey Quarterly Journal, Vol. 2, pp 169.
Humphery, C 1993, 'The audit expectations gap in Britain: an empirical investigation,

Accounting and Business Research', http:/ www.mckinsey.com/features/investors opinion/Vol. 23, No. 9l A, pp. 395-411.

Jensen, MC. and Fama, EE 1983, 'Separation of ownership and control', Journal of Law and Economics, Vol. 26, pp. 301-05.

Radhakrishnan R. \&Balasubramanian P. (2011),'Corporate Governance and India' CLEAR International Journal of Commerce and Management, Volume 1, issue 02, pp 130-135.

SarpalShivan(2014),'Interrelationship among Selected Voluntary Board Practices in Corporate Governance: Evidence from India', Indian Journal of Corporate Governance, Volume 7, No.2, pp 128. 